\title{
EARLY CRESTAL BONE STABILITY AROUND SUPRACRESTALY PLACED DENTAL IMPLANTS. A CASE SERIES
}

\author{
Saulius Žukauskas ${ }^{1}$, Algirdas Puišys², Paulius Andrijauskas ${ }^{1}$, Linas Zaleckas ${ }^{1}$, \\ Tomas Linkevičius ${ }^{1}$ \\ ${ }^{I}$ Institute of Dentistry of the Faculty of Medicine of Vilnius University, Lithuania, \\ ${ }^{2}$ Vilnius Implantology Center (private practice), Lithuania
}

Key words: gingival thickness, dental implant, crestal bone stability.

\begin{abstract}
Summary
Stability of crestal bone around dental implants is a major concern for oral surgeons and dentists. It is a key factor for success of dental implant treatment. Crestal bone is more prevented from resorption when surrounding tissues are thicker.

Aim of the study - to find out the mean of crestal bone loss around supracrestally placed dental implants with matching platform in vertically thick soft tissues. The final patient sample included 34 patients (17 female and 17 male), who received 34 two piece dental implants in total. All 34 implants integrated successfully as evaluation under implant success criteria was applied. Implants were restored by singleunit crowns, using metal-ceramic prostheses. After 1 year thick soft tissues maintain stable crestal bone around dental implants in lower jaw. Minor bone resorption of $0.28 \pm 0.36 \mathrm{~mm}$ mm could be seen during early bone remodelling phase.
\end{abstract}

\section{Introduction}

Stability of crestal bone around dental implants is a major concern for oral surgeons and dentists. It is a key factor for success of dental implant treatment. Bone around osseointegrated dental implants ensures function and support. Soft tissue forms biologic width, which is a natural barrier keeping bone safe from the bacteria in oral cavity. (1) As well as bone remodelation, biologic width formation is a physiologic phenomenon, which ensures to form proper amount of soft tissue for alveolar bone protection.

The term biologic width was based on the work of Gargulio et al in 1961 who described the dimensions and relationship of dentogingival junction in human cadavers. (2)
It has been hypothesised that a similar relationship of bone to overlying soft tissue exists around implants and changes in this relationship may be one of the reasons for the early crestal bone loss. Crestal bone is more prevented from resorption when surrounding tissues are thicker. It was first shown by T. Berglundh and J. Lindhe in their dog study. (3)5 beagle dogs were used. Extractions of ail mandibuiar premoiars were performed and 3 months later, 3 fixtures of the Branemark System ${ }^{\circledR}$ were installed in each side. Following 3 months of healing, abutment connection was carried out. On the right or left side of the mandible, abutment connection was performed according to the Branemark System ${ }^{\circledR}$ manual $\sim$ (control side In year 2006 implants with switching platform presented to market and a lot of studies stated that platform switching prevents crestal bone changes. Although, in these studies vertical soft tissue thickness was not measured. In recent study by Linkevicius, it was found that platform switching does not prevent crestal bone resorption if surrounding soft tissues are thin vertically (4) consisting of 6 implants with horizontally matching implant abutment connection (control Another study shows that in vertically thin $(<2.0 \mathrm{~mm})$ tissues mean early crestal bone loss is 1.35 $\mathrm{mm}$, in medium thick soft tissue $(2.1-3.0 \mathrm{~mm})-0.32 \mathrm{~mm}$, and thick $(>3.0 \mathrm{~mm})-0.12 \mathrm{~mm}$, although no significant statistical difference between bone loss between medium and thick tissues was found. (5)measured at the top of the crest can be referred to as thin, medium or thick and its influence on crestal bone loss around dental implants after a 1 year follow-up. Materials and Methods. Totally 64 implants were evaluated in 26 patients. 32 implants (test group As it was suggested to classify vertical gingiva thickness in two groups: vertically thin gingiva $(<3 \mathrm{~mm})$ and vertically thick gingiva (>3 mm). (6) Another factor that has influence on crestal bone loss is implant - abutment interface (microgap). Microgap is a feature of two piece implants which is related to crestal bone loss. In vitro studies have shown that due to 
implant-abutment interface there is a bacterial leakage along all the system. (7) This leakage is responsible for abutment related inflammatory cell infiltrate formation in soft tissues adjacent to microgap. $(8,9)$ In our study we take in consideration two main factors of crestal bone loss - vertical soft tissue thickness and microgap.

Aim of the study - to find out the mean of crestal bone loss around supracrestally placed dental implants with matching platform in vertically thick soft tissues.

\section{Materials and methods patients}

The study subjects were selected among partially edentulous patients of Vilnius University Zalgiris Clinic. Inclusion criteria were as follows: 1) thick mucosal tissues ( $3 \mathrm{~mm}$ or more), covering edentulous lower jaw alveolar ridge; 2 ) patient age 18 years or more; 3 ) healed bone sites (at least 3 months after tooth extraction); 4) sufficient alveolar ridge for $4.6 \mathrm{~mm}$ diameter implant placement $(>7 \mathrm{~mm}) ; 5$ ) no bone augmentation procedures before and during implant placement; 6) no medical contraindication for implant surgery; 7) signed informed consent for participation and permission to use obtained data for research purposes. Patients were excluded if they did not meet requirements listed above and also had the following: 1) poor oral hygiene; 2) symptoms or history of periodontitis or periimplantitis treatment; 3 ) poor cooperation relative to requirements for the study; 4) smoking; 5) alveolar ridges with bone defects at implantation sites; or 6) inadequate primary stability of implant, precluding healing abutment connection at the time of surgery. The final patient sample included 34 patients ( 17 female and 17 male), who received 34 two piece dental implants in total.

Implant placement. Implants with horizontally matching implant-abutment connection, $4.6 \mathrm{~mm}$ of diameter (Biohorizons, Birmingham, AL) were used. After the administration of $4 \%$ articaine solution (Ubistesin; 3M/ESPE, St Paul, MN) for local anesthesia, a midcrestal incision on the center of the edentulous ridge was performed. The buccal flap was raised and the mucosal thickness of the unseparated lingual flap was measured with $1 \mathrm{~mm}$ marked periodontal probe $(\mathrm{Hu}-$ Friedy, Chicago, IL) at the bone crest in the center of future implant placement. (Fig.1) This ensured direct visibility of gingival thickness measurement, then lingual flap was raised to expose the implant site.

The osteotomy site was measured to allow a minimum $1 \mathrm{~mm}$ range from adjacent tooth/teeth, and $1 \mathrm{~mm}$ space between buccal and lingual/palatal crest of the alveolar ridge and implant. Implants were placed approx. $0.5-1 \mathrm{~mm}$ above crestal bone. After implant placement, healing abutments were connected and 5/0 interrupted sutures (Polysorb; USSDG, Norwalk, CT) were placed. Flaps were approximated without tension and sutured without leaving gaps. Patients were instructed to rinse the operated site with $0.12 \%$ chlorhexidine-digluconate (Fresenius Kabi, Norge, AS, Norway) solution twice a day for a week. All patients received 7 day course of antibiotics of $1 \mathrm{~g}$ amoxicillin (Ospamox; Biochemie, Kundl, Austria) twice a day. For pain control, patients were prescribed $400 \mathrm{mg}$ of ibuprofen (Ibumax; Vitabalans Oy, Helsinki, Finland) to be taken as needed. The sutures were removed 7 to 10 days after the surgery. Patients were advised to clean healing abutments with a very soft tooth brush.

Restorative procedures. Based on conventional healing protocol, prosthetic procedures were initiated after 2 months of healing in the lower jaw. Impressions were taken using an open-tray technique. Apolyvinylsiloxane (Express, Espe, Germany) putty and correction material was used for a one step impression with the individual impression tray covered with adhesive. Screw retained porcelain fused to metal, fixed restorations were constructed and delivered to patients. After screwing, radiographic images were taken to ensure abutment seating

Patients were followed after 12 months after prosthetic treatment for oral hygiene procedures and evaluation of reconstruction. At each visit, the restorations were evaluated for mobility, periimplant soft tissue condition. Intraoral radiographs were taken to evaluate bone changes.

Radiographic assessment. Intraoral radiographs were taken with RVG Windows Trophy 5.0 (Trophy Radiology Inc., Paris, France) using a paralleling technique with Rinnlike film holder in high resolution mode. The images
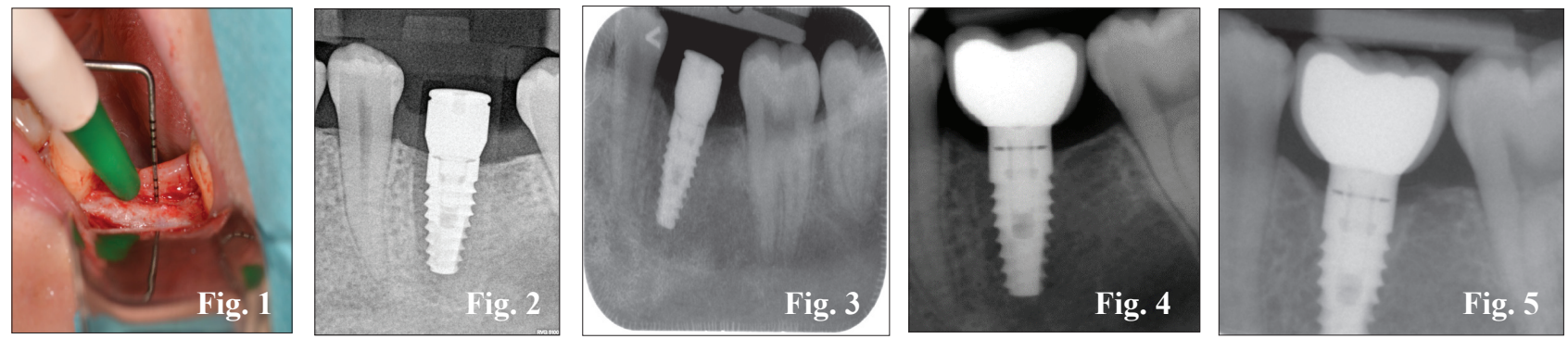
were obtained to ensure implant/abutment interface, and the threads were clearly visible. Before measurement, the parallelism of all intraoral radiographs was evaluated. Radiological evaluation and measurements were performed after implant placement (Fig. 2), after 2 months after surgical operation (Fig. 3), after prosthetic treatment (Fig. 4), and 1 year follow-up (Fig. 5) by one of the examiners using Adobe Photoshop and calibrating radiological images according to implant diameter.

\section{Results}

All 34 implants integrated successfully as evaluation under implant success criteria was applied. Implants were restored by single-unit crowns, using metal-ceramic prostheses. Mean mucosal thickness registered at the time of implant placement was $3.03 \pm 0.61 \mathrm{~mm}$ (range, 3 to $5.0 \mathrm{~mm}$ ) median $-3 \mathrm{~mm}$. Mean bone loss around implants after 2 months was $0.198 \pm 0.2 \mathrm{~mm}$, (range, 0.1 to $1.2 \mathrm{~mm}$ ), median - $0.1 \mathrm{~mm}$. After 1 year mean bone loss was $0.28 \pm 0.36 \mathrm{~mm}$, (range, 0.1 to $1.625 \mathrm{~mm}$ ), median $-0.15 \mathrm{~mm}$.

\section{Discussion}

This study investigated early bone resorption around dental implants in lower jaw. It could be concluded that thick tissue prevented crestal bone resorption in all cases of the study. This supports another study from Bergludh and Lindhe (3)5 beagle dogs were used. Extractions of ail mandibular premolars were performed and 3 months later, 3 fixtures of the Branemark System ${ }^{\circledR}$ were installed in each side. Following 3 months of healing, abutment connection was carried out. On the right or left side of the mandible, abutment connection was performed according to the Branemark System ${ }^{\circledR}$ manual $\sim$ (control side, which except differences in study methodology suggested the same conclusion. Another study from Linkevicius et all have reported mean bone loss when mucosa was thick $-0.26 \pm 0.08 \mathrm{~mm}$ on the mesial aspect and $0.09 \pm 0.05 \mathrm{~mm}$ on distal and mean bone loss around implants surrounded by thin mucosa $-1.8 \pm$ 0.164 and $1.87 \pm 0.166 \mathrm{~mm}$, during non-submerged implant placement. Although, one of differences was supracrestal implant placement of $0.5 \mathrm{~mm}$, which eliminated the effect of microgap. This study suggests that even dental implants without platform switching, could maintain stable crestal bone when the surrounding soft tissue is thick. However, there are a few limitations to the present study including a small sample size and case series, without comparison with different treatment approach. The results may differ with a larger sample size and longer evaluation period. So, further investigations are necessary to confirm the findings of our study.

\section{Conclusion}

Within the limitations of the study it can be concluded, that the initially thick soft tissues maintain stable crestal bone around dental implants in lower jaw. Minor bone resorption of $0.28 \pm 0.36 \mathrm{~mm} \mathrm{~mm}$ could be seen during early bone remodelling phase (1 year). It suggests that vertically thick soft tissue prevents crestal bone resorption around dental implants, even when implants without platform switching are used, placing them $0.5-1.0 \mathrm{~mm}$ supracrestally and lifting microgap above the bone crest.

\section{References}

1. Makigusa K. Histologic comparison of biologic width around teeth versus implant: The effect on bone preservation. J Implant Reconstr Dent [Internet] 2009;12(6):20-4. Available from: http://www.moderndentistrymedia.com/nov_dec2010/ makigusa.pdf

2. Gargiulo AW, Wentz FM, Orban B. Dimensions and relations of the dentogingival junction in humans. J Periodontol [Internet] 1961;32(3):261-7. Available from: http://www.joponline.org/ https://doi.org/10.1902/jop.1961.32.3.261

3. Berglundh T. Dimension of the periimplant mucosa Biological width revisited. J Clin Periodontol 1996;23(10):971-3.

https://doi.org/10.1111/j.1600-051X.1996.tb00520.x

4. Linkevicius T, Apse P, Grybauskas S, Puisys A. Influence of thin mucosal tissues on crestal bone stability around implants with platform switching: a 1 year pilot study. J Oral Maxillofac Surg 2010;68(9):2272-7.

https://doi.org/10.1016/j.joms.2009.08.018

5. Linkevicius T, Apse P, Grybauskas S, Puisys A. Reaction of crestal bone around implants depending on mucosal tissue thickness. A 1 year prospective clinical study. Stomatol Balt Dent Maxillofac J 2009.

6. Linkevicius T, Linkevicius R, Alkimavicius J, Linkeviciene L, Andrijauskas P, Puisys A. Influence of titanium base, lithium disilicate restoration and vertical soft tissue thickness on bone stability around triangular shaped implants: A prospective clinical trial. Clin Oral Implants Res 2018.

7. Dibart S, Warbington M, Su MF, Skobe Z. In vitro evaluation of the implant-abutment bacterial seal: the locking taper system. Int J Oral Maxillofac Implant 2005.

8. Abrahamsson I, Berglundh T, Sekino S, Lindhe J. Tissue reactions to abutment shift: An experimental study in dogs. Clin Implant Dent Relat Res 2003.

https://doi.org/10.1111/j.1708-8208.2003.tb00188.x

9. Ericsson I, Persson LG, Berglundh T, Marinello CP, Lindhe J, Klinge B. Different types of inflammatory reactions in periimplant soft tissues. J Clin Periodontol 1995.

https://doi.org/10.1111/j.1600-051X.1995.tb00143.x 


\section{4}

KAULO STABILUMAS APLINK DANTUU IMPLANTUS, POZICIONUOTUS VIRŠ KRAŠTINIO KAULO

S.Žukauskas, A.Puišys, P.Andrijauskas, L.Zaleckas, T.Linkevičius

Raktažodžiai: dantenų storis, danties implantas, kraštinio kaulo stabilumas.

Santrauka

Kraštinio kaulo stabilumas aplink dantų implantus yra svarbus faktorius, nusakantis ilgalaikị gydymo rezultatą odontologijoje. Irodyta, kad kraštinis kaulas prie dantų implantų išsaugomas, kai minkštieji audiniai yra vertikaliai stori.

Tyrimo tikslas - nustatyti vidutinị kraštinio kaulo patirpimą aplink dantų implantus ịsriegtus virš kraštinio kaulo, kai minkštieji audiniai yra vertikaliai stori.
Tyrime dalyvavo 34 pacientai (17 vyru ir 17 moteru), kuriems buvo įsriegti 34 dantų implantai. Visiems implantams prigijus be komplikacijų, jie protezuoti metalo keramikos vainikèliais. Kraštinio kaulo būklè vertinta: po operacijos, po 2 mènesių nuo operacijos, prieš protezavimą ir 1 metai po protezavimo. Gautas rezultatas - vidutinis kraštinio kaulo patirpimas $0,28 \pm 0,36$, stebimas dèl ankstyvos kaulo remodeliacijos.

Adresas susirašinėti:saul.zuk@gmail.com

2019-03-28 